Annals of Tropical Research 29(3): 1-14 (2007)

\title{
Improving Commercial Possibilities of Non-wood Forest Products from Leyte, the Philippines
}

\section{Celeste Lacuna-Richman}

\author{
Faculty of Forestry \\ University of Joensuu \\ PO Box 111, Joensuu 80101 \\ Finland
}

\begin{abstract}
Current literature regarding the economic potential of non-wood forest products (NWFPs) has become more cautious than previously, and earning an income from NWFPs is no longer considered a certainty for dwellers in many forested areas. However, there is also more information on the NWFPs, the areas from which there can be sustained collection and the markets where they can be competitive. This paper discusses some of the considerations to be taken into account to prevent costly mistakes in choosing NWFPs for commercialisation. It also highlights the possibilities for particular products to improve their prospects in markets from the local to the national and international level, using information from literature and past data on NWFPs in Leyte Province in the Philippines as an illustration. Past data include a list of several NWFPs from Cienda, Leyte. A table of relative frequency of use was assembled from this list after two rounds of interviews, to form the basis for possibly marketable NWFPs using a provisional template.
\end{abstract}

Keywords: success factors, marketing guidelines, subsistence products, growth commodities, high-value niche services, template for guidelines

\section{INTRODUCTION}

The promise held by non-wood forest products (NWFPs) as an alternative to either timber harvesting or agricultural expansion as a source of income for forest dwellers has been emphasised in the literature. Recent experience suggests that although this promise still exists, the situation is not as optimistic as previously thought due to limitations of the natural and social environment surrounding these products, and the economic situation during market entry. However, there are some factors that increase the likelihood of a NWFP becoming a viable source of revenue just as there are considerations that may lessen the success of a NWFP in its transformation from subsistence to commercial product. In this paper, these 'do's and don'ts' are presented in the context of the existing NWFPs collected and used in Leyte Province, the Philippines. 
Among the recent literature, Scherr et al. (2004) of the Centre for International Forestry Research have outlined the factors that both encourage and hinder the use of forest products for improving opportunities of low-income producers. The contributors discussed the supply and demand factors for NWFPs (and other products) that would open a niche for their sale in the domestic and possibly export market. The discussion regarding NWFPs that successfully provide income for their collectors can be divided into economic, social and ecological aspects. The latter has been discussed extensively in the context of increasing commercialization of NWFPs by Peters (1996), who raised the question of sustainability. The risks associated with commercialization, from both intensive and extensive harvesting, to the livelihood of collectors, have been examined by Belcher and Schreckenberg (2007) who concluded that there are no riskfree NWFPs for commercialization. Relevant national policy and a thorough consideration of the entire value chain are considered as key social and economic factors for the success of NWFP commercialization by the authors. These are also the conclusions of an earlier study (Velde et al. 2006). However, it is almost inevitable that NWFPs will be used to generate income by people who live in forest areas despite the risks, and initiatives for reducing the ecological, social and economic risks are needed.

The analysis by CIFOR is preceded by such comparative studies on NWFPs as that between Guatemala and Indonesia (Salafsky et al. 1993), wherein the authors sifted through the socio-economic and political factors that affect NWFP commercial success. Another practical evaluation of such factors on the marketing of NWFP species in West Kalimantan, Indonesia, was reported by De Jong and Utama (1998), who identified bamboo and rattan as the most marketable NWFPs from a list of promising species.

The objective of this paper is to make a template of guidelines, with 'success factors' on the vertical axis, and species to be considered for NWFP commercialisation on the horizontal axis, using Leyte's non-wood forest products as an example. Factors that affect NWFP marketing are presented, and data about common non-wood forest products in Leyte Province and the relative frequency of their use are reported. In the final part of the paper, a hypothetical, partial template of non-wood forest product scores on each factor is used to illustrate the process.

\section{CONSIDERATIONS FOR NWFP COMMERCIALISATION}

The factors that should be considered before non-wood forest products could be commercialised fall into three main groups, namely ecological, social and economic factors.

\section{Ecological Factors Affecting NWFP Marketing}

The most basic factors that have to be taken into account when considering a NWFP for commercialization are usually ecological. These are the characteristics of the NWFP that ensure a favourable relationship with its natural environment. This is so because although it may be possible to grow almost any plant anywhere in the world with the necessary structures and inputs, NWFPs are frequently lowmaintenance or zero-maintenance vegetation. This is the reason why NWFPs are 
within reach of many subsistence farmers or forest dwellers, while other natural resources often are not.

Ironically, only after these ecological factors are addressed is be possible to attend to the social ones, and only after the proper social conditions are in place is it possible to fulfil economic factors. Yet it often happens that the attempt to commercialise NWFPs only takes into account one of these three main groupings of factors, usually depending on the background of the promoter: businessmen emphasize the economic promise of a NWFP, non-government organisations its social benefits, and environmentalists the possibility of using NWFPs as a stop-gap measure to prevent turning a forest to some other land use.

An essential ecological factor is the amount of the product available in the forest at present and in the immediate future. In relation to this, it is necessary to ask if there is enough of the NWFP to supply the market without cultivation. Finally, if cultivation is needed for commercialization, an all-important consideration is whether there is land available for it without encroaching on land used for other necessary purposes. The relative importance of NWFPs in conjunction with tree species for different forest types is illustrated by cases from India, China, Australia and the Philippines (Harrison and Herbohn 2001). This work shows that different forest types give a diverse range of potential for NWFPs, from conifer or eucalypt monocultures leaving little nontimber value, to community managed timber plantations allowing high NWFP importance. However, the issues of social equity and the dangers of commercialization were common in all case areas.

A list of the NWFPs used by people in Cienda in Leyte Province in the Philippines (Table 1) illustrates some possibilities for a NWFP enterprise; these species are both known and used by local forest communities. The list was developed in a previous study on the NWFPs commonly collected near Baybay, Leyte (Lacuna-Richman 2002), although other lists from studies of Leyte NWFPs are also available. Of these NWFPs, a few are well established as commercial products, among them rattan and various types of bamboo. Most non-wood forest products collected in the Cienda area are used purely as subsistence products, meaning that they are neither bought nor sold, and a few are on the border between being subsistence and commercial goods.

Table 1. Non-wood forest products used by the villagers of Cienda, Leyte Province

\begin{tabular}{lll}
\hline Scientific name & \multicolumn{1}{c}{ Local name } & \multicolumn{1}{c}{ Plant part and uses $^{\mathrm{a}}$} \\
\hline $\begin{array}{l}\text { Artocarpus heterophyllus } \\
\text { Lamarck }\end{array}$ & Nangka & Fruit, seeds (food) \\
$\begin{array}{l}\text { Athyrium esculentum Copeland } \\
\text { Bambusa sp.; Dendrocalamus }\end{array}$ & Pako & Kawayan \\
$\begin{array}{l}\text { sp.; Schizotachium spp. } \\
\text { Bixa orellana L. }\end{array}$ & Atsuete/suete & Stems (building material) \\
\hline
\end{tabular}


Table 1. (Cont)

\begin{tabular}{|c|c|c|}
\hline Scientific name & Local name & Plant part and uses ${ }^{\mathrm{a}}$ \\
\hline Blumea balsamifera (L.) DC. & Gabon/gabun & Leaves (medicinal) \\
\hline Cajanus cajan (L.) Huth. & Kadyos & Seeds (food) \\
\hline Calamus sp. & $\begin{array}{l}\text { Rattan/sika/limuran/ } \\
\text { yantok/ubod }\end{array}$ & $\begin{array}{l}\text { Pith and fruits (food), Stems } \\
\text { (furniture, handicraft) or } \\
\text { labong (when used as food) }\end{array}$ \\
\hline Caryota cumingii Lodd. & Pugahan & Leaves (food) \\
\hline Chrysophyllum cainito L. & Kaymito/caimito & $\begin{array}{l}\text { Leaves (medicine), fruit } \\
\text { (food) }\end{array}$ \\
\hline Cinnamomum cebuense Kost. & Kaningag & Bark (medicine) \\
\hline Colocasia esculenta (L.) Schott. & Gabi & Leaves, shoots, root (food) \\
\hline Dioscorea hispida Dennst. & Kuyot/kot & Tuber (food) \\
\hline Gmelina sp. & Tuba-tuba & $\begin{array}{l}\text { Leaves (decoction } \\
\text { medicinal) }\end{array}$ \\
\hline Gnetum gnemon L. & Bago & Leaves, shoots (food) \\
\hline Ipomoea reptans Poir. & Tangkung/kangkong & Leaves \\
\hline Moringa oleifera Lamarck * & Kamunggay/malunggay & Fruit (food), leaves (food) \\
\hline Musa ctv. & Saging/banana & $\begin{array}{l}\text { Fruit, inflorescence (food); } \\
\text { leaves (wrapping material) }\end{array}$ \\
\hline \multirow[t]{2}{*}{ Nypa fruticans Wurmb. } & Nipa & Leaves (building material) \\
\hline & Batbat & Pith (food) \\
\hline Odontanema nitidum (Jacq.) & Atay-atay & Leaves (medicine) \\
\hline Persea Americana & Abokado & Leaves (medicine), \\
\hline Pogostemon heyneanus Bth. & Kadlom/kadlum & Leaves (medicine) \\
\hline Psidium guajava $\mathrm{L}$. & Guyabas/bayabas & $\begin{array}{l}\text { Leaves (medicine), fruit } \\
\text { (food) }\end{array}$ \\
\hline $\begin{array}{l}\text { Xanthosoma sagittifolium (L.) } \\
\text { Schott }\end{array}$ & Takudo/pakodo & Tuber (food) \\
\hline \multicolumn{3}{|c|}{ Others, scientific name not determined: } \\
\hline & Hayom-hayom & Leaves (food) \\
\hline & Kinabugahay & Leaves (food) \\
\hline & Kojaji & Fungi (food) \\
\hline & Labkos/libgos/libkos & \\
\hline & Orchids(various) & Whole plant (ornamental) \\
\hline & Pichay-pichay & Leaves (food) \\
\hline & Tago-sabaw & Fungi (food) \\
\hline & Tangog-tangog & Fungi (food) \\
\hline & Wild ginseng & $\begin{array}{l}\text { Stems, roots (medicine, } \\
\text { beverage) }\end{array}$ \\
\hline
\end{tabular}

a. All references to the use of species for food indicate human food, except for Moringa oleifera leaves, which are also used as a food supplement for livestock. 


\section{Social Factors in Marketing NWFPs}

There were two main tendencies in the past when transforming subsistence NWFPs into commodities. One was to consider large-scale commercialization based on the product itself, e.g. does this item (plant, animal, or view) have a potential market, and if so, how can this market be accessed? Or, conversely, the development of NWFPs to generate income is treated as a minor aspect of a larger project, e.g. to allow people (including women, landless agricultural workers, indigenous people and other target groups) an income when timber harvesting is not allowed. Although both approaches and others are useful and sometimes necessary, they tend to limit the appeal of NWFPs as a possible income source on a smaller, local scale from many more who could benefit, especially in areas with widespread poverty. Rarely are NWFPs treated as the primary products for improving the economic life of every household within forest communities. Yet these models do exist and provide many examples for 'best practices' lists.

The study by Salafsky et al. (1993) emphasized that the main social factors necessary for a NWFP enterprise to succeed are resource tenure and conservation incentives, the availability of physical and social infrastructure for transporting the products, absence of alternative land-use pressure, and political power for the producers. The presence of these factors was crucial to the success of NWFP enterprises in Peten, Guatemala and Kalimantan, Indonesia, the sources of data for their study.

In a more recent study, social factors that affect the economic success of forest products were itemized based on a study of indigenous forestry businesses in the USA. The findings (Cornell 2001, as cited by Scherr et al. 2004) emphasized that self-rule is a necessary, though not self-sufficient condition because it encourages clear links between decisions and effects. The study also pointed out that non-politicized mechanisms for resolving disputes, formal institutions for governance, and long-term strategic planning for development of the community, also enable a forest business to work. The findings of this study run counter to ideas that economic success is dependent on resource endowment, location, or advanced education. Common points among the Salafsky, Cornell, and other studies of social factors that affect successful forestry enterprises show that proper decision-making by the main stakeholders predominates other socioeconomic characteristics usually thought to be more important, such as formal education.

Although these social factors would be difficult to institutionalize completely, there are some government programs in the Philippines which attempt to ensure that such factors are emphasized in forest management. In Leyte, there are some communities that have successfully earned their Community Based Forestry Management Agreement (CBFMA), which allows them a 25-year tenure over their local forest land, that is renewable for a further 25 years if the communities are able to manage their forest according to specific criteria. A basic criterion for obtaining a CBFMA is the presence of a working farmer community organization in the proposed area.

Table 2 reports the familiarity and frequency of use of NWFPs in Cienda, the Leyte community that shares a CBFM Agreement with its neighbouring sitio (village) of San Vicente. A list of the most commonly used NWFPs was compiled after face-to- 
face interviews with the head of the household within the community. From this list, questions regarding the frequency of use were put forth in a second round of interviews. Most respondents identified the NWFPs on the list. Reported frequency of usage varied from not being used at all to 'used on a daily basis'. Extensive knowledge of the NWFPs within the community could mean that it is not necessary to introduce the species before they can be processed into marketable products, since familiarity exists. The frequency of use may provide an indication of how saleable the NWFP could be, and which niche it could fill. For example, avocado (a cultivated fruit introduced from Central America which is often found growing wild in Leyte forests) is used by a large percentage of the households, but most use it on a seasonal basis (yearly) or irregularly. It is highly marketable, but perhaps more on the national rather than local scale, where there may be too many sellers and a surplus of supply.

Table 2. Relative frequency of non-wood forest product subsistence use in Cienda, Leyte

\begin{tabular}{|c|c|c|c|c|c|c|c|c|}
\hline \multirow{2}{*}{$\begin{array}{l}\text { Plant } \\
\text { (common } \\
\text { name) }\end{array}$} & \multicolumn{7}{|c|}{ Frequency of use by percentage of households } & \multirow{2}{*}{$\begin{array}{c}\text { Total } \\
\text { Identified } \\
(\%) \\
\mathrm{n}=41^{\mathrm{b}}\end{array}$} \\
\hline & $\begin{array}{c}\text { Known, } \\
\text { not } \\
\text { used }\end{array}$ & Daily & Weekly & Monthly & Yearly & $\begin{array}{c}\text { Used } \\
\text { irregularly }\end{array}$ & $\begin{array}{l}\text { Used } \\
\text { often }^{\mathrm{a}}\end{array}$ & \\
\hline Atay-atay & 12.2 & 0 & 0 & 7.32 & 22 & 31.71 & 0 & 73.17 \\
\hline Avocado & 0 & 0 & 2.44 & 9.76 & 41.46 & 46.34 & 0 & 100 \\
\hline Bago & 2.44 & 0 & 17.07 & 70.73 & 7.32 & 2.44 & 0 & 100 \\
\hline Bayabas & 0 & 9.76 & 36.6 & 24.4 & 2.44 & 22 & 4.88 & 100 \\
\hline $\begin{array}{l}\text { Caimito/ } \\
\text { kaymito }\end{array}$ & 0 & 0 & 4.88 & 4.88 & 80.5 & 9.76 & 0 & 100 \\
\hline Gabi & 4.88 & 9.76 & 46.34 & 17.07 & 0 & 17.07 & 4.88 & 100 \\
\hline $\begin{array}{l}\text { Hayom- } \\
\text { hayom }\end{array}$ & 9.76 & 0 & 0 & 26.81 & 19.51 & 26.81 & 0 & 83 \\
\hline Honey & 0 & 0 & 17.07 & 12.02 & 34.15 & 36.6 & 0 & 100 \\
\hline Kadyos & 31.71 & 0 & 0 & 2.44 & 7.32 & 4.88 & 0 & 46.34 \\
\hline $\begin{array}{l}\text { Kamunggay } \\
\text { (malunggay) }\end{array}$ & 0 & 48.8 & 41.46 & 0 & 0 & 7.32 & 2.44 & 100 \\
\hline Kangkong & 0 & 9.76 & 78.05 & 7.32 & 0 & 4.88 & 0 & 100 \\
\hline Kaningag & 2.44 & 0 & 0 & 2.44 & 19.51 & 73.17 & 0 & 97.6 \\
\hline Kawayan ${ }^{c}$ & 0 & 0 & 0 & 19.51 & 78.05 & 2.44 & 0 & 100 \\
\hline Kinabugahay & 14.63 & 0 & 0 & 2.44 & 2.44 & 0 & 0 & 19.51 \\
\hline $\begin{array}{l}\text { Kojaji } \\
\text { (mushroom) }\end{array}$ & 9.76 & 0 & 2.44 & 24.4 & 43.9 & 19.51 & 0 & 100 \\
\hline $\begin{array}{l}\text { Labkos } \\
\text { (ligkos or } \\
\text { libgos) }\end{array}$ & 2.44 & 0 & 0 & 4.88 & 87.8 & 4.88 & 0 & 100 \\
\hline Orchids & 17.07 & 2.44 & 0 & 0 & 2.44 & 70.73 & 0 & 92.7 \\
\hline Pako & 0 & 22 & 56.1 & 17.07 & 0 & 4.88 & 0 & 100 \\
\hline
\end{tabular}


Table 2. (Cont.)

\begin{tabular}{|c|c|c|c|c|c|c|c|c|}
\hline \multirow{2}{*}{$\begin{array}{l}\text { Plant } \\
\text { (common } \\
\text { name) }\end{array}$} & \multicolumn{7}{|c|}{ Frequency of use by percentage of households } & \multirow{2}{*}{$\begin{array}{c}\text { Total } \\
\text { Identified } \\
\quad(\%) \\
\mathrm{n}=41^{\mathrm{b}}\end{array}$} \\
\hline & $\begin{array}{l}\text { Known, } \\
\text { not used }\end{array}$ & Daily & Weekly & Monthly & Yearly & $\begin{array}{c}\text { Used } \\
\text { irregularly }\end{array}$ & $\begin{array}{l}\text { Used } \\
\text { often }^{\text {a }}\end{array}$ & \\
\hline Pakodo & 0 & 14.63 & 46.34 & 19.51 & 4.88 & 14.63 & 0 & 100 \\
\hline $\begin{array}{l}\text { Pichay- } \\
\text { pichay }\end{array}$ & 14.63 & 0 & 2.44 & 9.76 & 34.15 & 19.51 & 0 & 80.5 \\
\hline Pugahan & 0 & 0 & 12.2 & 68.3 & 7.32 & 9.76 & 0 & 97.6 \\
\hline Saging ${ }^{\mathrm{d}}$ & 0 & 4.88 & 58.54 & 17.07 & 0 & 19.51 & 0 & 100 \\
\hline $\begin{array}{l}\text { Rattan } \\
\text { Tago- }\end{array}$ & 51.22 & 0 & 4.88 & 0 & 31.70 & 12.2 & 0 & 100 \\
\hline $\begin{array}{l}\text { sabaw } \\
\text { Tangog- }\end{array}$ & 24.4 & 0 & 2.44 & 12.2 & 29.27 & 4.88 & 0 & 73.17 \\
\hline $\begin{array}{l}\text { tangog } \\
\text { Tuba- }\end{array}$ & 2.44 & 0 & 12.2 & 29.27 & 17.07 & 36.6 & 0 & 97.6 \\
\hline $\begin{array}{l}\text { tuba } \\
\text { Fraction } \\
\text { identified } \\
(\%)\end{array}$ & 2.44 & $7 \%$ & $19 \%$ & 4.88 & 12.2 & 75.61 & $0.67 \%$ & 100 \\
\hline
\end{tabular}

a. The NWFP is used more than once daily, if readily available.

b. The percentage is that of heads of households surveyed who identified the plant correctly.

c. The specific part of the plant referred to is 'labong' or edible shoots of the bamboo.

d. The specific part of the plant referred to is the 'puso' or flower, which is eaten as a vegetable.

Source: Lacuna-Richman (2002).

\section{Economic Factors Affecting Prospects for Commercialisation}

NWFPs are in general low-value products, which make them less attractive to larger forestry entrepreneurs. In addition, they usually involve low costs for market entry, which makes them accessible to the majority of forest product entrepreneurs who are poor. The various reasons for the ideal place of NWFPs for poverty alleviation are grouped by the CIFOR studies into demand, supply, and market characteristics (Scherr et al. 2004, p. 30).

\section{The demand for marketable non-wood forest products}

NWFPs are products with a growing demand as well as having low market entry costs, thus they indefinitely allow for the entry of more new entrepreneurs. Small and uneven volumes and flexible quality standards for raw materials also allow small producers to leave the market as easily as they can enter it, which is not an easy option for producers who have incurred large capital outlays.

A favourable demand situation which may favour small producers of NWFPs could only occur if other conditions already exist. Among these conditions are unrestricted bidding processes and a large number of buyers for raw materials, which 
would result in higher prices and more equitable terms for producers. Before these are set in place however, there should be existing demand for the NWFP; otherwise, small producers will find it very difficult to create demand at a fair market price. The importance of existing demand is illustrated well by comparisons of the domestic markets for rattan in Laos, Viet Nam and Cambodia (Evans 2002). The market for rattan works has the potential for working in these countries, depending on their stage of development. Vietnam has exhausted wild stocks of rattan, but is developing plantations. Cambodia also has diminishing wild stocks, but plantations have not yet been well-established. It is Laos, which began plantation establishment even with considerable wild stocks still intact, and the added advantage of $a$ steady demand for a sub-product, edible rattan shoots, that has the strongest potential for rattan staying in the market. Also, the market intermediaries for small-scale collectors of NWFPs usually provide 'bundling', or offering a combination of financing, technical support, and marketing for the raw materials that assists the small producers. Yet, depending on the existence of competition among such middlemen, small producers may become too dependent on one such intermediary, to their disadvantage.

\section{Supply considerations for non-wood forest products}

The supply factors mentioned by Scherr et al. (2004) that make NWFPs ideal for generating income for poor entrepreneurs are almost all based on the assumption that these products are relatively plentiful. Nonetheless, they do point to clear advantages for small producers. Most NWFPs are produced with low-cost technologies which are locally known, and can thus be easily modified according to what the market demands as well as the production cost.

If NWFP marketing is tied in with international or the national initiatives of governments or non-governmental organizations regarding environmental conservation, then there is a possibility that NWFPs would supplement income from production, for instance, from agriculture or industry, instead of being replaced by these. This is an important supply issue in countries such as the Philippines, where the scarcity of land for agriculture or capital for industry excludes many people in forest communities from venturing into the market. Support for NWFP marketing encourages such communities not only to preserve their forest, but also to value the species used for NWFPs as a source of income. The non-timber benefits from forests including NWFPs are well-documented (Herbohn et al. 2000), but support for marketing is mostly concentrated on wood products (Harrison 2000).

At present, little importance is given to non-wood forest products in many forest communities because of the low prices offered for them in relation to cultivated produce or manufactured goods. For example, NATRIPAL (United Tribes of Palawan), a non-government organization which among its other functions helps indigenous communities in Palawan Province market their products, is sometimes faced with the lack of interest by forest communities to value-added NWFPs. This is due to the communities' previous discouraging experiences in trying to sell NWFPs, in which the price offered to them by infrequent tourists was negligible and transport of products to even the local marketplaces was too expensive (Alsa and Banua 2004). 


\section{The market for non-wood forest products}

The characteristics of market entry that make NWFPs a feasible income source for small producers still exist for most NWFPs. According to Scherr et al. (2004), these are low regulatory costs of market entry, no producer subsidies (which favours large producers), low-cost regulation, and secure local rights. However, all or some of these factors may not be present once a NWFP becomes broadly accepted as a commodity, and measures must be taken to avoid conditions wherein there are high costs of market entry in the form of regulation and uncertain local rights for the resource. For example, a monopoly on the processing of a NWFP such as resin might lead to the rise of concession licensing, similar to what is required of timber harvesting. Legal support may prove unaffordable to collectors, leading to the criminalization of NWFP collection, which occurs once a product becomes scarce in open-access forests. This had been the experience with licensing of rattan collection in the Philippines (Tesoro 2002). Secure local rights to forest areas and for the right to collect forest products have been, and are still being applied for by many forest dwellers in the form of CBFM Agreements and other such legal instruments for forest use in the Philippines.

Another major consideration about the market for NWFPs is its size and scope. Size refers to how small or large the current market for a NWFP is, and its potential for either expanding or contracting. Even though many NWFPs are lower-value products sold locally with little integration with national markets, successful integration with national markets can make these growth commodities. Some NWFPs which have successfully made the transition into growth commodities are medicinal plants, forest fruits and spices. Those NWFPs that remain as stagnant market commodities may be sold in large volumes, but are considered inferior goods, and lose buyers as incomes grow or lower priced substitutes become available. NWFPs used as thatching, rough furniture and basketry fall into this category. Although not ideal as products that should be developed further, these are important because they usually are the easiest products for the poor to use to enter the market.

A further category by size of market is high-value niche services - products that are highly specialized and differentiated from other competitors. Unfortunately, these kinds of services are found often only in developed or high-income countries and highly developed markets. In some cases, handicrafts from NWFPs that are valued for the craftsman's 'brand name' rather than for the raw material used are considered high-value niche goods. These goods are often grouped together with high-value niche services, such as ecotourism packages, when income from forests is calculated.

The scope for NWFPs becoming commercialized can range from their entering local, to national, to international markets. As the size of the market depends on the type of product, so also does the scope of possible commercialization depend on the market size. NWFPs used for poverty alleviation purposes are usually sold on a local scale, but national and international expansion is not unknown. The latter condition is especially true for high-value niche goods and services, when there are ties with national or international partners, who are willing to assist in product design so as to take into account the requirements of the 'target clientele' and 
specifically market these products to these clients. If this is possible, further concerns would necessarily be where to find these partners, and how to ensure that the locus of control for the NWFP lies with the community producing it. In summary, the factors that would positively affect a NWFP's sustainable entry into the markets are presented in Table 3.

Table 3. Factors that improve chances of successful commercialisation of NWFPs

\section{Ecological}

The NWFP grows easily and regularly in the area, with little input, whether it is endemic or not (temporal availability)

The NWFP grows densely in many areas

Various NWFPs can be harvested complementary to each other

The NWFP is familiar to the people in the area

The NWFP has some local uses (is not considered a weed)

How much of the NWFP is presently available in the forest

Land availability if cultivation is needed

\section{Social}

Self-rule regarding the enterprise

Conservation incentives

Non-politicised mechanisms for resolving disputes

Formal institutions for governance

Long-term strategic planning for development from the community and the political power to see it through

\section{Economic}

\section{Supply:}

The raw product is relatively plentiful

Processing requires low cost technology

Marketing is tied with government, non-government organisation or business initiatives

Does not have unresolved conflict with alternative uses of land or other resources

Demand:

Small and uneven volumes allow producers to leave and enter the market easily

Unrestricted bidding processes

Large number of buyers for raw materials

Presence of and competition among able middlemen to facilitate market entry and prevent dependence of producers on one dealer

The market:

Low regulatory costs of market entry

No producer subsidies (which favours large producers)

Low-cost regulation

Secure local rights to land and for forest product collection 


\section{A HYPOTHETICAL TEMPLATE OF GUIDELINES}

Using Leyte's NWFPs in making a template of guidelines, the economic, social and ecological factors are placed on the vertical axis, and the species to be considered for NWFP commercialization on the horizontal axis. Each factor is assigned a particular value for its importance in the local context, determined by present and future stakeholders in developing the NWFP resource. A Likert scale of 1 to 5 can be used for each factor, with 1 being not viable and 5 highly viable for the specific factor. For example, for supply factors: low-cost technology in processing (5); easy modification of production process (5); possible assistance to enter the national market (4); and possible assistance to export (5). A NWFP with a total of 20 points, for instance, could be given priority for development over one with a lower score.

A hypothetical, partial template is presented in Table 4. It is based on the species in Table 2 that have the highest relative frequencies of use, and the factors for NWFP marketability as presented in Table 3. The non-wood forest products chosen as examples are those with a high frequency of use, and the factors included are those previously listed as ecological and social considerations.

The value that is assigned for each NWFP, on every factor, is determined by each well-informed stakeholder in the planned enterprise. The concept of stakeholders in a forest enterprise is discussed in the context of farm forestry by Harrison (2000), and could be defined as individuals or groups who have a commercial or 'quality of life' interest in the enterprise. In the Cienda example, the main stakeholders are the members of the community, thus the initial basis for considering a NWFP is its correct identification by local community and the relative frequency of its use. The selection of a smaller list of NWFPs would require either individual or group interviews on the feasibility of marketing the products on the list. Subsequent stakeholder interviews may be with local NWFP dealers, forest service personnel, and even potential buyers of such products. It is also highly likely that different stakeholders may have different fields of expertise. For example, the collectors themselves and ecological researchers may have more knowledge about occurrence of the NWFPs in the forest than policymakers. In such cases, the template can be divided into three sections, with all three sections sharing the same list of possible NWFPs, but with a different heading on the vertical axis (ecological, social or economic). These various sections will be combined after completion. Thus, when preparing the final matrix, there would be some agreement among experts about the commercialisation possibilities of a selected number of NWFPs.

In the hypothetical example in Table 4, there is little difference in the total scores of the selected products. In such a situation, other factors, such as the desirability of the product to the consumers, may influence the final decision to commercialize. For example, the taste of one edible forest product may be preferred by more users than that of another product which has the same total score. Even in such cases, the template would allow specific potential problems in commercialization to be noticed, an example here being the higher regulatory costs for market entry in selling honey. 
Table 4. Partial template of factors for marketing specific non-wood forest products

\begin{tabular}{|c|c|c|c|c|c|c|}
\hline $\begin{array}{l}\frac{n}{0} \\
\mathscr{d} \\
\omega\end{array}$ & 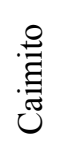 & 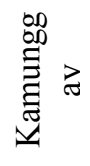 & 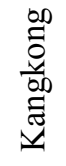 & 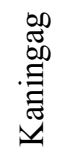 & 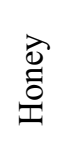 & $\frac{\infty}{\frac{0}{0}}$ \\
\hline \multicolumn{7}{|l|}{ Considerations } \\
\hline \multicolumn{7}{|l|}{ 1. Ecological } \\
\hline $\begin{array}{l}\text { NWFP grows easily and regularly in the area, } \\
\text { with little input }\end{array}$ & 5 & 5 & 5 & 5 & 5 & 5 \\
\hline NWFP grows densely in many areas & 2 & 4 & 3 & 3 & 3 & 4 \\
\hline $\begin{array}{l}\text { NWFPs can be harvested complementary to each } \\
\text { other }\end{array}$ & 3 & 3 & 4 & 4 & 4 & 4 \\
\hline NWFP is familiar & 5 & 5 & 5 & 5 & 5 & 5 \\
\hline NWFP has some local uses & 5 & 5 & 5 & 5 & 5 & 3 \\
\hline NWFP supply is abundant without cultivation & 3 & 4 & 4 & 4 & 4 & 4 \\
\hline Land is available for NWFP cultivation if needed & 2 & 2 & 2 & 2 & 2 & 2 \\
\hline \multicolumn{7}{|l|}{ 2. Social } \\
\hline Self-rule regarding the enterprise & 5 & 3 & 3 & 3 & 4 & 3 \\
\hline Conservation incentives & 2 & 4 & 4 & 4 & 5 & 5 \\
\hline $\begin{array}{l}\text { Non-politicised mechanisms for resolving } \\
\text { disputes }\end{array}$ & 4 & 4 & 4 & 4 & 4 & 4 \\
\hline Formal institutions for governance & 1 & 1 & 1 & 1 & 1 & 1 \\
\hline $\begin{array}{l}\text { Long-term strategic planning for development } \\
\text { from the community }\end{array}$ & 2 & 1 & 1 & 1 & 3 & 2 \\
\hline \multicolumn{7}{|l|}{ 3. Economic } \\
\hline Product is relatively plentiful & 5 & 5 & 5 & 5 & 5 & 3 \\
\hline Processing requires low-cost technology & 5 & 5 & 5 & 5 & 3 & 4 \\
\hline $\begin{array}{l}\text { Producers can enter and leave the market easily } \\
\text { despite small and uneven volumes }\end{array}$ & 4 & 4 & 4 & 4 & 4 & 3 \\
\hline Low regulatory costs for market entry & 5 & 5 & 5 & 5 & 3 & 3 \\
\hline $\begin{array}{l}\text { Secure local rights to land and for forest product } \\
\text { collection }\end{array}$ & 3 & 5 & 5 & 5 & 3 & 3 \\
\hline Total & 61 & 65 & 65 & 65 & 63 & 58 \\
\hline
\end{tabular}

\section{CONCLUDING COMMENTS}

Evidence presented in current literature shows that NWFPs may not be the primary solution to biodiversity loss, deforestation, poverty of forest dwellers and other related problems, but NWFPs have some important functions for alleviating these problems, especially in tropical forests. The choice of which NWFPs to develop and market has been for the most part based on random criteria, some of which are validated by 
widespread acceptance of the NWFP by consumers, others failing immediately. There is sufficient literature on NWFPs at present to identify the ecological, social and economic factors that contribute to a specific NWFPs success as a market product. However, application of these factors when deciding which NWFPs to develop is less commonly practiced, particularly among lesser known products that, unlike for example, rattan, are little known by people outside the collectors' immediate forest area. The use of a simple template and Likert scale by stakeholders in a NWFP enterprise, using familiar forest species and a checklist of well-established factors, would aid the selection of NWFPs for development by making it easier and more systematic.

\section{REFERENCES}

ALSA, L. and D. BANUA. 2004. Sales of Rattan and Honey. NATRIPAL. Puerto Princesa City, Palawan, the Philippines.

BELCHER, B. and K. SCHRECKENBERG. 2007. Commercialization of non-timber forest products: A reality check. Development Policy Review. 25(3): 355-377.

DE JONG, W. and R. UTAMA. 1998. 'Turning ideas into action: planning for non-timber forest product development and conservation', in E. Wollenberg and A. Ingles, (eds.), Incomes from the Forest: Methods for the Development and Conservation of Forest Products for Local Communities. CIFOR and IUCN, Bogor, Indonesia.

EVANS, T. 2002. The status of the rattan sectors in Lao People's Democratic Republic, Viet Nam and Cambodia - with an emphasis on cane supply. In: Rattan: Current Research Issues and Prospects for Conservation and Sustainable Development (J. Dransfield, F.O. Tesoro and N. Manokaran, eds). Food and Agriculture Organisation of the United Nations (FAO), Rome.

HARRISON, S.R. 2000. Socio-economic and policy issues in farm forestry. In: Sustainable Small-scale Forestry: Socio-Economic Analysis and Policy (S.R. Harrison, J.L. Herbohn and K.F. Herbohn, eds). Edward Elgar, Cheltenham.

HARRISON, S.R. and J.L. HERBOHN. 2001. The Importance of Non-Timber Products in Tropical Small-Scale Forestry. In: Sustainable Farm Forestry in the Tropics: Social and Economic Analysis and Policy (S.R. Harrison and J.L. Herbohn, eds). Edward Elgar, Cheltenham.

HERBOHN, J.L, HARRISON, S.R., LAMB, D. and R. KEENAN. 2000. Small-scale forestry systems for timber and non-timber benefits including biodiversity. In Sustainable Small-scale Forestry: Socio-Economic Analysis and Policy (S.R. Harrison, J.L. Herbohn and K.F. Herbohn eds). Edward Elgar, Cheltenham.

LACUNA-RICHMAN, C. 2002. The socioeconomic significance of subsistence non-wood forest products in Leyte, Philippines. Environmental Conservation. 29(2): 253-262.

PETERS, C.M. 1996. Observations on the sustainable exploitation of non-timber tropical forest products In: Current Issues in Non-Timber Forest Products Research (M. Ruiz Perez and J.E.M. Arnold, eds). Centre for International Forestry Research. Bogor, Indonesia.

SALAFSKY, N., DUGELBY, B.L. and J.W. TERBOUGH. 1993. Can extractive reserves save the rain forest? An ecological and socioeconomic comparison of non-timber forest product extraction systems in Peten, Guatemala and Kalimantan, Indonesia. Conservation Biology. 7(1): 39-52. 
SCHERR, S.J., WHITE, A. and D. KAIMOWITZ. (eds) 2004. A New Agenda for Forest Conservation and Poverty Reduction: Making Markets Work for Low-Income Producers. Washington, DC: Forest Trends, Centre for International Forest Research (CIFOR). World Conservation Union (IUCN).

TESORO, F.O. 2002. Rattan resources of the Philippines, their extent, production, utilisation and issues on resource development. In: Rattan: Current Research Issues and Prospects for Conservation and Sustainable Development (J. Dransfield, F.O. Tesoro and N. Manokaran, eds). Food and Agriculture Organisation of the United Nations (FAO). Rome.

VELDE, D.W., RUSHTON, J., SCHRECKENBERG, K., MARSHALL, E., EDOUARD, F., NEWTON, A. and ARANCIBIA, E. 2006. Entrepreneurship in value chains of nontimber forest products. Forest Policy and Economics. 8(7): 725-741. 